\title{
PRINCIPLES OF ECONOMETHICS FROM THE GIFFEN DEMAND
}

\author{
J. Agustín FRANCO \\ Department of Economics, Faculty of Law, University of Extremadura, \\ Av. University, 1, 10004 Cáceres, Spain
}

Received 26 July 2011; accepted 27 April 2013

\begin{abstract}
This paper raises an approach to the study of consumer behaviour and markets with a particular emphasis on agricultural commodities. It develops an analysis of demand for certain products during a recent economic recession in Spain by showing the behaviour of some of them as Giffen goods in some years. According to the theory of Giffen demand, there is a direct (positive) relationship between price and the quantity demanded. Thus, the income effect outweighs the substitution effect. The main contributions of this work can be summarized in the next three points: 1) This paper studies the consumer behaviour from a Giffen perspective, beyond a traditional and rational utility approach; 2) It also suggests a framework to analyse several socioeconomic proposals and theories related to the sustainability and Human Rights-based ethic level (intrinsic to Giffen behaviour); 3) Finally, this theory is a significant contribution to design better economic policies. The analysis of Giffen phenomenon has greater explanatory power than the classical theory of Marshall. It also helps to reveal a number of important effects that are usually ignored and that could contribute to clarify some current economic phenomena.
\end{abstract}

Keywords: Giffen demand, inferiority condition, agricultural commodities, Spain, ethics paradigm.

JEL Classification: A12, C15, C80, D01, E22.

\section{Introduction}

The theory of Giffen or positive-sloping demand states that there is a direct relationship between price and quantity demanded (given a set of conditions), calling seriously into question the law of downward-sloping demand set out by Marshall (1890). Giffen demand is an exception to the Law of Demand (the quantity demanded of a good increases if its price decreases). Economists have long recognized that the axioms of consumer theory do not guarantee that demand curves must slope downward. According to Jensen and Miller (2008), the Law of Demand, descriptively valid in many situations, may not apply to very

Corresponding E-mail:

franco@unex.es 
poor consumers facing subsistence concerns. In sum, there are three reasons that explain an upward demand: poverty (Giffen theory), luxury (Veblen theory) and speculative behaviour or theory of the "generalized panic" (Torres, Córdoba 1992).

The Giffen paradox was popularized by Marshall in 1895 who attributed it improperly to Robert Giffen. Nevertheless, Marshall was not the only author who studied upward demand in circumstances of subsistence (e.g. both Pareto in 1896 and Wicksell in 1901 also analysed this topic). According to Stigler (1947) Simon Gray in 1815 was the first to provide "Giffen evidence". It was published in a book chapter entitled "A rise in the price of bread corn, beyond a certain pitch, tends to increase the consumption of it" (Haagsma 2012). Giffen phenomenon has played a theoretically and empirically controversial role in the history of economic thought. The lack of strong evidence has showed this topic more as a paradox of economic theory than as a real behaviour (at the micro and macro levels).

Although Giffen demand has potentially greater explanatory power than classical demand, it has generally been ignored despite many authors having cited and studied the "Giffen paradox" (Stigler 1947; Silberberg, Walker 1984; Battalio et al. 1991; McKenzie 2002; Luptacik 2010; Attanasio et al. 2012; Minagawa 2012). Its explanatory power is relevant in contexts or situations which most closely approach reality, for which studies of consumer behaviour and purchaser motivation show that the traditional hypothesis of rationality has been relaxed. Giffen demand also explains better the subsistence situations among impoverished people and developing countries according to Jensen and Miller (2008). Also the theory of Giffen demand allows us link economic theory and business marketing, topics which are frequently treated separately in the usual Economics handbooks (e.g. Blanco 2008; Mochón 2010).

The marketing perspective on Giffen demand allows us develop an alternative explanation of consumer behaviour that is more extensive than the Marshallian law of decreasing demand, offering a broader analytical framework and leading a reinterpretation of the traditional explanation (e.g. Attanasio et al. 2012; Minagawa 2012). It does not invalidate or preclude phenomena of inverse relationships between price and quantity demanded, although such relationships are only verifiable for intervals of usual sale prices, as indeed was acknowledged by Marshall (1890), and remain a conjecture for other situations.

From the marketing standpoint, one can be more precise about the details not only of the type of rationality exhibited by the consumer, but also of the transformation of the perception of luxury goods into (inferior) staple goods, those in which the income effect outweighs, or even completely nullifies, the substitution effect.

The traditional conditions for the emergence of Giffen goods arise in an economic context of permanent crisis, combined with continued reductions in income (Jensen, Miller 2008), thus generating a state of insecurity that leads to all consumer activity being considered as the consumption of staples. Marketing strategy and consumer income levels affect whether the nature of goods change from normal to inferior and vice versa, depending on the economic circumstances (e.g. Minagawa 2012; Kamphorst, Swank 2013; Minten et al. 2013). In the following, we shall examine various aspects of the demand function based on the fundamental concepts presented in most introductory undergraduate economics textbooks 
(e.g. Blanco 2008; Mochón 2010). Moreover, we can also agree with Balder, "that there is probably no mathematically rigorous textbook on micro-economics theory" (Heijman, Von Mouche 2012).

This paper tries to analyze two questions: Is it possible to widen the study scope of Giffen theory in the XXI century? Is the economic crisis creating Giffen behaviour in the agrifood markets? In particular, the main contributions of this paper can be summarized in three points: 1) It studies consumer behaviour from a Giffen perspective, beyond a traditional and rational utility approach. It also helps to reveal a number of important effects that are usually ignored and that could contribute to clarify some current economic phenomena, especially, family and social support networks during economic crisis periods; 2) It suggests a framework to analyse several socioeconomic proposals and theories related to poverty, sustainability and Human Rights-based ethics (intrinsic to Giffen behaviour); 3) It contributes to design better economic policies considering Giffen phenomenon. Moreover, the analysis of Giffen demand has potentially greater explanatory power than the classical theory of Marshall.

This paper will highlight, within a theoretical framework, several effects that were previously ignored because of their ethical implications. At the empirical level, this is the first study whose objective is the analysis of the Giffen phenomenon in the present financial and economic crisis situation in Europe. The results show some Giffen behaviour in Spanish fruits and vegetables demand. Several implications are related to these results, especially at policy recommendations level. On the one hand, it is necessary to redesign the economic programmes of fight against poverty taking into account the Giffen behaviour. On the other hand, agrifood policies must incorporate the Giffen consequences by income levels.

Table 1 resumes the aim topics related to the Giffen phenomenon according to the revision of theoretical (Heijman, Von Mouche 2012) and empirical literature (Jensen, Miller 2008; Xingang, Pingkuo 2013).

Table 1. Redefining laws of market and others basic economic concepts

\begin{tabular}{|c|c|c|}
\hline Item & Neoclassical approach & Giffen approach \\
\hline Preferences & Convex & Concave \\
\hline Maximization procedure & Utility & Utility and non-utility \\
\hline Laws of demand and supply & Fixed (downward and upward) & Variable \\
\hline Law of equilibrium & $\begin{array}{l}\text { Invisible hand. Individual } \\
\text { rationality. }\end{array}$ & Collective rationality \\
\hline $\begin{array}{l}\text { Law of equality of weighted } \\
\text { marginal utilities }\end{array}$ & $\begin{array}{l}\text { Ignored constraint } \\
\text { (unitary correction factor) }\end{array}$ & Variable correction factor \\
\hline Theoretical analysis & $\begin{array}{l}\text { Supply and Demand } \\
\text { independents. } \\
\text { Competitiveness }\end{array}$ & $\begin{array}{l}\text { S and D inter-dependents. } \\
\text { Cooperation. }\end{array}$ \\
\hline $\begin{array}{l}\text { Nature of goods and } \\
\text { behaviours }\end{array}$ & Normal & Inferior \\
\hline Prices changes & $\begin{array}{l}\text { Only Substitution and Income } \\
\text { effects }\end{array}$ & $\begin{array}{l}\text { Additional (endogenous) income } \\
\text { effect }\end{array}$ \\
\hline Giffen phenomenon & Rare, infrequent, curiosity & $\begin{array}{l}\text { Real, frequent. } \\
\text { Concealed at the aggregate level. }\end{array}$ \\
\hline
\end{tabular}


Continued Table 1

\begin{tabular}{|c|c|c|}
\hline Item & Neoclassical approach & Giffen approach \\
\hline Capacity of individual choice & Flexible, only budget constraints & $\begin{array}{l}\text { Exogenous and endogenous } \\
\text { constraints }\end{array}$ \\
\hline $\begin{array}{l}\text { Impacts of speculative } \\
\text { behaviours }\end{array}$ & Not important & Giffen behaviour \\
\hline Public control of speculation & Not important & A priori and a posteriori mechanisms \\
\hline Prices & Fiable indicator & Non-fiable indicator \\
\hline Market & $\begin{array}{l}\text { Hypothesis: Free market. } \\
\text { Theory: Efficiency and market } \\
\text { "failures". } \\
\text { Evidence: Capital vs Labour. }\end{array}$ & $\begin{array}{l}\text { Hypothesis: Beyond neoclassical } \\
\text { market. } \\
\text { Theory: Unrealistic free market. } \\
\text { Evidence: Redistribution. }\end{array}$ \\
\hline Entrepreneurial initiative & Private risk. Ignored social risk & Explicit social risk \\
\hline Private property & Absolute. HHRR subordinated. & $\begin{array}{l}\text { Vulnerable to speculation. } \\
\text { Basic needs no covered. }\end{array}$ \\
\hline $\begin{array}{l}\text { Alternative economic } \\
\text { paradigm }\end{array}$ & Unnecessarily. Limited proposal. & Very important \\
\hline
\end{tabular}

The main outlines of the paper can be summarized in these main epigraphs. Revision of Giffen demand theory, empirical analysis on the possibility of Giffen evidence in some Spanish agrifood products among the years of the economic crisis from 2006 to 2010, policy recommendations and conclusions.

\section{Revising the economic theory from the Giffen demand}

\subsection{The classical theory of Giffen phenomenon}

The classical Giffen theory begin drawing this scenario: An individual consumer with a choice problem, i.e. an optimization problem, the maximization of the utility under a fixed-income constraint, which spend proportionally $(\alpha)$ in two goods, $\mathrm{X}$ and $\mathrm{Y}$. This approach understands the price changes, the price-elasticity of demand (Ep), as the sum of two effects, income and susbtitution effects, boths are measured by means their elasticity respective ( $I e$ and $\mathrm{Se}$ ) according to the Slutsky equation (Eq. (1)):

$$
\mathrm{TE}=\mathrm{IE}+\mathrm{SE} \rightarrow \mathrm{Ep}=-(\alpha \mathrm{I} e+(1-\alpha) \mathrm{Se}) .
$$

In Eq. (1) we define the total price effect (TE) as the sum of substitution effect (SE) and income effect (IE). This expression does not include additional constraints as the endogenous income (here also named "saving effect").

Table 2 resumes all possible situations from the Slutsky equation. For example, if the income elasticity is positive (negative) then $\mathrm{X}$ is a normal (inferior) good. When the income effect outweighs the substitution effect then the demand function of good X is upward sloping (Giffen good). That is, if the consumer spends a significant portion of his income in the inferior good and if the substitution-elasticity is negligible, then the demand for this good will have a segment with increasing slope. 
Table 2. Income and Substitution Effects (IE and SE)

\begin{tabular}{cccc}
\hline \multicolumn{2}{c}{ Income effect (IE) } & Good & Relationship between Price and Quantity \\
\hline $\begin{array}{c}\text { IE }>\mathbf{0} \\
\text { Reinforces the SE }\end{array}$ & Normal & Inverse \\
\cline { 1 - 2 } $\begin{array}{c}\text { IE }<\mathbf{0} \\
\text { counteracts SE }\end{array}$ & If $\mid$ IE $|<|$ SE $\mid$ & Inferior & Direct \\
\cline { 1 - 3 }
\end{tabular}

However and according to Haagsma (2012), if we consider that people behave either as demanders (buyers of present consumption) and as suppliers (sellers of savings deposits), then the price effect Ep (the price-elasticity of demand) will be different to fixed-income situation. Now the new Slutsky equation (Eq. (2)) will contain this saving decision ( $\beta$ ):

$$
\mathrm{TE}=\mathrm{IE}+\mathrm{SE}+\mathrm{SaE} \rightarrow \mathrm{Ep}=-(\alpha I e+(1-\alpha) \mathrm{Se})+\beta I e .
$$

Therefore, when the price of good X falls, the sign of the total income effect depends on the nature (normal or inferior) of good $\mathrm{X}$ and the saving level.

Moreover, Georgescu-Roegen (1954) established four basic principles in relation to the problem of choice. He concludes that the goods are potentially substitutable only if they satisfy the same category of need. This implies that substitution effects can only occur among similar goods associated with the same need. The Ng's (1972) method of optimization by steps is based on this observation. On the other hand, variations in demand are more dependent on income effects than substitution effects, as shown by the Post-Keynesians and Institutional approaches and empirical studies (Fernández-Huerga 2008). Thus, substitution effect is neither dominant nor as important as generally assumed in neoclassical economics.

\subsection{The equilibrium situations}

A simple graphical analysis of growing supply and demand suggests that surpluses of both supply and demand can occur either above or below the equilibrium point, depending on the relative slopes of the curves. In particular, if the Giffen demand has a slope less than that of the supply, then supply surpluses will occur at quantities and prices below equilibrium (demand more elastic than supply).

In contrast, demand surpluses will occur above the equilibrium. Instead, the classic situation will be the case when the slope of the Giffen demand is greater than that of the supply (demand less elastic than supply).

For example, given a Giffen demand that is more elastic (flatter) than the supply, in a zone of excess supply (below equilibrium) the trend towards equilibrium will involve a price increase, since the demand is willing to pay a higher price for each additional unit of the good demanded (Fig. 1). And as this adjustment takes place, the quantity supplied and demanded also increases.

Starting from an initial equilibrium situation, a reduction in supply (shift in parallel to the left) can lead to an increase in price and the equilibrium quantity if the demand remains constant or increases and is more inelastic than the supply (Table 3). The effect on the new equilibrium will be indeterminate if the demand is also reduced, and will depend on the magnitude of the shift and the relative slopes of the curves (Tables 4.1 and 4.2). 


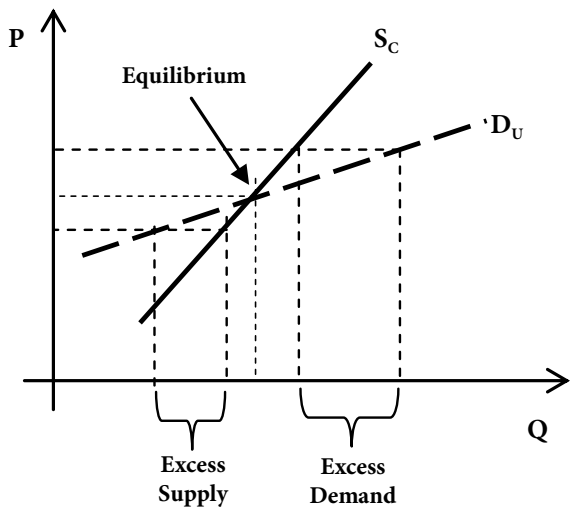

Fig. 1. Graphical representation of upward demand and classical supply

Table 3. Effect on the price and quantity of equilibrium of shifts in the Giffen demand and classical supply curves (when the demand is more / less elastic than the supply)

\begin{tabular}{cccc}
\hline SHIFTS & $\mathrm{S}_{\mathrm{C}}$ constant & $\mathrm{S}_{\mathrm{C}}$ increase & S $_{\mathrm{C}}$ decrease \\
\hline $\mathrm{D}_{\mathrm{G}}$ constant & $\mathrm{P} \& \mathrm{Q}$ constant & $\mathrm{P} \& \mathrm{Q} \uparrow / \downarrow$ & $\mathrm{P} \& \mathrm{Q} \downarrow / \uparrow$ \\
\hline $\mathrm{D}_{\mathrm{G}}$ increase & $\mathrm{P} \& \mathrm{Q} \downarrow / \uparrow$ & $\mathrm{P} \& \mathrm{Q} ?$ & $\mathrm{P} \& \mathrm{Q} \downarrow / \uparrow$ \\
\hline $\mathrm{D}_{\mathrm{G}}$ decrease & $\mathrm{P} \& \mathrm{Q} \uparrow / \downarrow$ & $\mathrm{P} \& \mathrm{Q} \uparrow / \downarrow$ & $\mathrm{P} \& \mathrm{Q} ?$ \\
\hline
\end{tabular}

Notes: Giffen demand $\left(\mathrm{D}_{\mathrm{G}}\right)$. Classical supply $\left(\mathrm{S}_{\mathrm{C}}\right)$. Price $(\mathrm{P})$ and quantity $(\mathrm{Q})$. "Increases" are parallel shifts to the right. "Decreases" are parallel shifts to the left. Uncertain effect on prices and quantities is indicated by a question mark "?". In the new equilibrium, the first arrow means the situation when the demand is more elastic than the supply. The second arrow means the scenario when the supply is more elastic than the demand.

Table 4.1. Simultaneous shifts (Increases) of Giffen demand and classical supply in the same direction

\begin{tabular}{ccc}
\hline Magnitude of shift & \multicolumn{2}{c}{ Giffen demand and classical supply increase both } \\
\cline { 2 - 3 } & $\mathrm{D}_{\mathrm{G}}$ more elastic than $\mathrm{S}_{\mathrm{C}}$ & $\mathrm{D}_{\mathrm{G}}$ less elastic than $\mathrm{S}_{\mathrm{C}}$ \\
\hline $\mathrm{S}_{\mathrm{C}}>\mathrm{D}_{\mathrm{G}}$ & Situation 1: $\mathrm{P}$ ? and $\mathrm{Q} \uparrow$ & Situation 2: $\mathrm{P} \downarrow$ and $\mathrm{Q}$ ? \\
(larger shift in classical supply) & Consumerism of inelastic supply & De-growth of elastic supply \\
\hline $\mathrm{D}_{\mathrm{G}}>\mathrm{S}_{\mathrm{C}}$ & Situation 3: $\mathrm{P} \downarrow$ and $\mathrm{Q}$ ? & Situation 4: $\mathrm{P}$ ? and $\mathrm{Q} \uparrow$ \\
(larger shift in Giffen demand) & De-growth of elastic demand & Innovation of inelastic demand \\
\hline
\end{tabular}

Notes: Giffen demand $\left(\mathrm{D}_{\mathrm{G}}\right)$. Classical supply $\left(\mathrm{S}_{\mathrm{C}}\right)$. Price $(\mathrm{P})$ and quantity $(\mathrm{Q})$. "Increases" means parallel shifts to the right. Uncertain effect on prices and quantities is indicated by a question mark "?".

Table 4.2. Simultaneous shifts (Decreases) of Giffen demand and classical supply in the same direction

\begin{tabular}{ccc}
\hline Magnitude of shift & \multicolumn{2}{c}{ Giffen demand and classical supply decrease both } \\
\cline { 2 - 3 } & $\mathrm{D}_{\mathrm{G}}$ more elastic than $\mathrm{S}_{\mathrm{C}}$ & $\mathrm{D}_{\mathrm{G}}$ less elastic than $\mathrm{S}_{\mathrm{C}}$ \\
\hline $\begin{array}{c}\mathrm{S}_{\mathrm{C}}>\mathrm{D}_{\mathrm{G}} \\
\text { (larger shift in classical supply) }\end{array}$ & $\begin{array}{c}\text { Situation 5: } \mathrm{P} \text { ? and } \mathrm{Q} \downarrow \\
\text { Speculation of supply (if } \mathrm{P} \uparrow \text { ) } \\
\text { De-growth of inelastic supply }\end{array}$ & $\begin{array}{c}\text { Situation 6: } \mathrm{P} \uparrow \text { and } \mathrm{Q} \text { ? } \\
\text { Innovation of elastic supply }\end{array}$ \\
\hline $\begin{array}{c}\mathrm{D}_{\mathrm{G}}>\mathrm{S}_{\mathrm{C}} \\
\text { (larger shift in Giffen demand) }\end{array}$ & $\begin{array}{c}\text { Situation 7: } \mathrm{P} \uparrow \text { and } \mathrm{Q} \text { ? } \\
\text { Consumerism of elastic demand }\end{array}$ & $\begin{array}{c}\text { Situation 8: } \mathrm{P} \text { ? and } \mathrm{Q} \downarrow \\
\text { Speculation of demand (if } \mathrm{P} \uparrow \text { ) } \\
\text { De-growth of inelastic demand }\end{array}$ \\
\hline
\end{tabular}

Notes: Giffen demand $\left(\mathrm{D}_{\mathrm{G}}\right)$. Classical supply $\left(\mathrm{S}_{\mathrm{C}}\right)$. Price $(\mathrm{P})$ and quantity $(\mathrm{Q})$. "Decreases" means parallel shifts to the left. Uncertain effect on prices and quantities is indicated by a question mark "?". 
The situation described provides a more plausible explanation to the traditional example of potatoes in Ireland during the famine of 1845 (Dwyer, Lindsay 1984). In particular, it serves to refute the objection of those who argue that, given a Giffen demand, a reduced harvest would necessarily entail a fall in price.

Although the simultaneous variation of supply and demand in the same sense has an uncertain effect on the new equilibrium price, some interesting trends can be observed. Tables 4.1 and 4.2 develop eight situations related to simultaneous shifts of Giffen demand and classical supply. Particularly, two interesting results are deduced from these tables: The existence of four types of Giffen-based degrowth and the incentive for speculative behaviours.

\subsubsection{Theory of Giffen-based degrowth (situations $2,3,5$ and 8)}

In a phase of economic expansion, when demand is less elastic than supply (Situation 2), the equilibrium quantity decreases only when supply increases faster than demand (Shultz model for Giffen demand). If demand is more elastic than supply (Situation 3), the equilibrium quantity decreases only when demand is rising faster than supply.

In economic recession, when demand is more elastic than supply, the equilibrium price only goes down when supply reduction is considerably greater than demand (Situation 5 ). We will talk about speculative markets only if the shift in supply is not large and, consequently, prices increase. Conversely, when demand is more inelastic than supply, the price only drops when demand reduction is faster than supply (Situation 8). We will talk about speculative markets only if the decline in demand is not very big and, consequently, prices increase.

\subsubsection{Theory of Giffen-based consumption (situations 1 and 7)}

Tables 4.1 and 4.2 show that both consumerist and speculative activities are likely because of the high possibility of an artificial raise of prices. We can observe in Situation 1 (booming economy) that price only goes up when supply is increasing faster than demand (being demand more elastic than supply). This defines our well-known "consumerist society" and the continued dynamism in product innovation. In this scenario speculative practices act as an allocation and regulation mechanism of wasteful capacity towards those consumers who wish more a product and not towards those consumers who need it most, who are excluded from the market. If the economy is in crisis period, Situation 7 shows that the equilibrium quantity goes up only when demand reduction is considerably greater than supply. Again, the phenomenon of market exclusion appears affecting those consumers with lower purchasing power.

\subsubsection{Theory of Giffen-based innovation (situations 4 and 6)}

Regarding Giffen-based innovation, Tables 4.1 and 4.2 show that the responsibility for innovation relies more heavily on those agents more sensitive to changes in prices, that is, suppliers. Artificial raise of prices means an incentive for the development of speculative markets.

Economic expansion period (Situation 4) shows that when supply is more elastic than demand, the equilibrium price only goes up when increased demand is considerably greater than supply. "Markets for new products" would be found in this scenario. This situation is likely to further protect the property rights of innovations because supply is more sensitive (elastic) 
than demand to price changes. However, in an economic recession scenario, the equilibrium quantity will increase only if the decrease in supply (exit of firms from the market) is significantly greater than demand (Situation 6), so that there is a more efficient reallocation of production. This is also explained by the higher price-elasticity of supply.

\subsection{The "Saving Effect"}

The condition of normality of a good is based on the existence of a positive substitution effect. In traditional analysis, this substitution effect is present in all goods, including inferior goods. Thus an inferior good exists if there is a normal good which absorbs the transfer of quantity demanded from one good to another in response to changes in income or budget constraint $(R)$ or relative prices (e.g. Blanco 2008). However, this characteristic is very restrictive and not universal since it invalidates the existence, or at least the meaningful analysis, of two inferior goods when income or relative prices change (inferiority condition) and the behavioural complementarity too (Chambers et al. 2010).

In other words, an increase in income or purchasing power (due to a relative decline in prices) can only simultaneously diminish the demand for two inferior goods if there is a saving effect in one of the goods on the theoretically optimal quantity attainable. Thus, the saving effect acts in the opposite direction to the substitution effect of false-normal good. The classical explanation assumes, however, that the saving effect is null, which implies the transformation of the inferior good into a false-normal good (Fig. 2) and it also implies the negation of the "distribution effect" (social foundation) existing at the base of the individual's economic decision making (Cortina 2011).

The method used to decompose the total effect of a price change in substitution effect and income effect is analysing what would happen if the substitution effect occurs first and then the income effect, rather than both happen simultaneously. In other words, we decompose the total effect of price changes, first, analysing only the change in relative prices and, second, analysing only the change in purchasing power. Step 1 (substitution effect): It is considered the effect of a change in relative prices (e.g. $\mathrm{P}_{\mathrm{X}} \uparrow$ ) without changing the purchasing power, that is, a variation of the slope of the budget constraint - it expresses that good $\mathrm{X}$ has become relatively more expensive - without the consumer moves from the initial indifference curve. Step 2 (income effect): Now it is considered the effect of a change in the purchasing power without changing relative prices, that is, the budget constraint moves parallel towards the indifference curve closer to the origin.

In Figure 2, $X$ is an inferior good and $Z$ too (or false-normal) and there is a decrease in the price of good $X$ (disposable budget increases). Therefore, the budget constraint moves in the direction of good $X$, from $\left(R / P_{X}\right)_{1}$ to $\left(R / P_{X}\right)_{2}$. In Figure 3 there is an increase in the price of good $X$ (disposable budget decreases). Thus, the budget constraint is moved towards the origin of the axis of the good X. In both figures, point A is the initial situation on the consumer's budget constraint, $B$ is an intermediate position to identify income and substitution effects, and $\mathrm{C}$ is the final position on the new budget constraint. Indifference curves are $u_{1}$ and $u_{2}$. In both situations the individual can spend the entire budget in consumption (of $X$ and $Z$ ) or saving something, according to the extended Slutsky Eq. (2). 


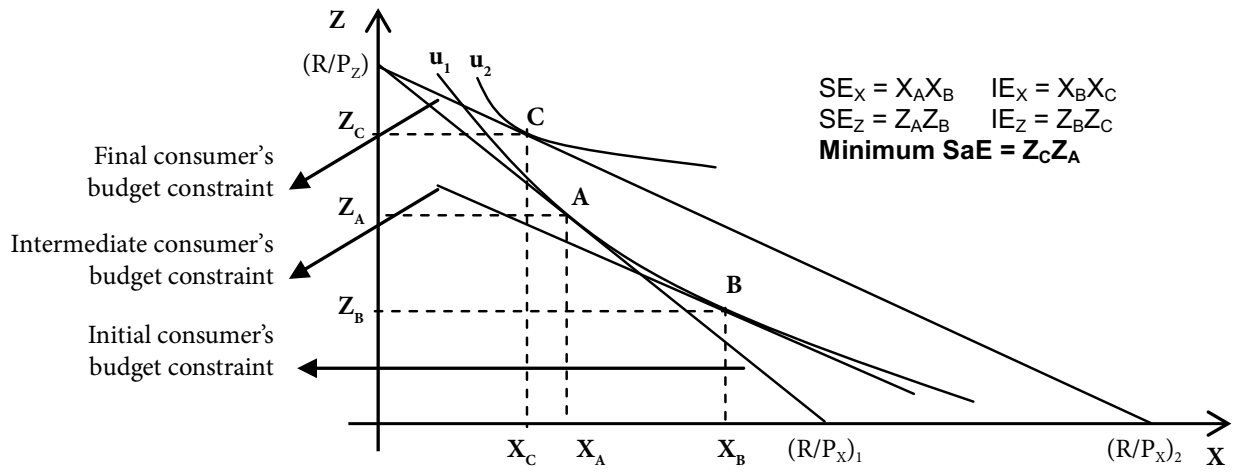

Fig. 2. Graphical representation according to the Hicks' classical view of the Saving Effect when there are two inferior goods and $\mathrm{P}_{\mathrm{X}}$ falls

Notes: Quantities of goods $\mathrm{X}$ and $\mathrm{Z}$ in the initial, intermediate and final equilibrium situations (A, $B$ and $C$ respectively). Substitution effects for both goods $\left(\mathrm{SE}_{\mathrm{x}}\right.$ and $\left.\mathrm{SE}_{\mathrm{z}}\right)$ and income effects $\left(\mathrm{IE}_{\mathrm{X}}\right.$ and $\left.\mathrm{IE}_{\mathrm{Z}}\right)$. Saving effect $(\mathrm{SaE})$. Initial and final indifference curves $\left(\mathrm{u}_{1}\right.$ and $\left.\mathrm{u}_{2}\right)$. The points of intersection with the axes are calculated from the budget constraint: $R=X P_{X}+Z P_{Z}$.

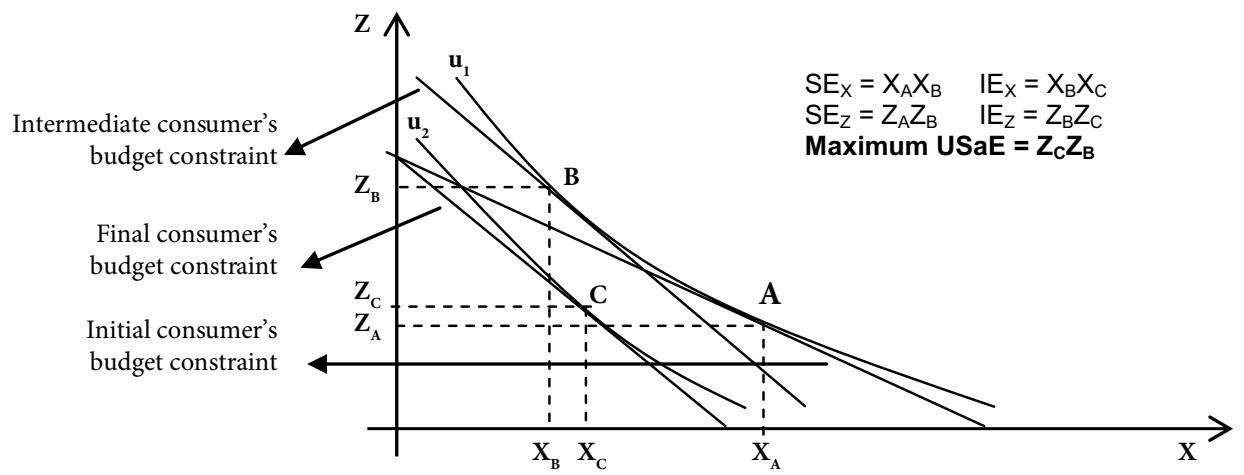

Fig. 3. Graphical representation according to the Hicks' classical view of the Unsaving Effect when there are two inferior goods and $\mathrm{P}_{\mathrm{X}}$ rises

Notes: Quantities of goods $\mathrm{X}$ and $\mathrm{Z}$ in the initial, intermediate and final equilibrium situations

(A, $B$ and $C$ respectively). $X$ and $Z$ substitution effects $\left(\mathrm{SE}_{\mathrm{X}}\right.$ and $\left.\mathrm{SE}_{\mathrm{Z}}\right)$ and income effects

$\left(\mathrm{IE}_{\mathrm{X}}\right.$ and $\left.\mathrm{IE}_{\mathrm{z}}\right)$. Unsaving effect (USaE). Initial and final indifference curves $\left(\mathrm{u}_{1}\right.$ and $\left.\mathrm{u}_{2}\right)$.

The points of intersection with the axes are calculated from the budget constraint: $R=X P_{X}+Z P_{Z}$

In Figure 2 the saving effect can reach a minimum value equivalent to $Z_{C} Z_{A}$ segment, in the case that the consumer would decide don't spend his entire budget. If there is a decrease in income or purchasing power (Fig. 3) then the demand for the two inferior goods can only increase due to an unsaving effect, which can reach a maximum value equivalent to $Z_{C} Z_{B}$ segment, in the case that the consumer would decide spend all his budget and more (unsaving decision). Consumer could unsaving only if previously he had saved something individually or socially (family, charity, public social protection programmes). Obviously, this situation compromises the classical map of indifference curves. The unsaving effect acts in the same direction to the substitution effect of false-normal good. 
According to the extended Slutsky equation, the total price effect is the sum of substitution effect, income effect and saving effect (SaE) or unsaving effect (USae) in this way (Eq. (3)):

$$
\begin{aligned}
\mathrm{TE}= & \mathrm{SE}+\mathrm{IE}+\mathrm{SaE} \text { (or USaE) } \\
& \text { If } \mathrm{SaE}=0 \rightarrow \text { Classical model (simple Slutsky equation). }
\end{aligned}
$$

A situation in which all goods are inferior responds more closely to the economics problem of scarcity and choice, as it suggests the need for interdependence among demanders. The choice problem between two goods is no longer regarded only as between the individual and his or her income, but is social, inter-individual. The distributive consequences of the explanation of the saving/unsaving effect involve the recognition in the field of positive economics of a subject traditionally relegated to the field of normative economics. It implies the recuperation of "political economy" concept.

The critical economic problem is not with scarcity and the possibility of choice. It is the low possibility of choice because of the lack of alternative opportunities. Thus, the opportunity cost is infinite when there is no possibility of choice, since any alternative that improves the initial situation will always be preferable. The exclusive consideration of normal goods avoids this crucial economic problem (Chambers et al. 2010). Hence, based on the substitution effect, there could be possibility for negotiation, speculation or renunciation of some basic human rights as food (Medina, Cascante 2011; Franco 2011). The scarcity-based choice paradox is that in the classical picture the possibility of choice becomes a luxury so abundant, a concept so hiper-rational and economicist, that it not consider other possibilities more realistic, less evident, more universal, less paradoxical and more economically decisive such as the impossibility level to choose freely because of several additional exogenous and endogenous constraints or rigidities (Huck, Rasul 2011; Attanasio et al. 2012; Minagawa 2012; Xingang, Pingkuo 2013; Minten et al. 2013; Kamphorst, Swank 2013).

Exogenous restrictions are subsistence conditions, nutritional complementarities or non-income barriers such as the minimum time for certain consumptions. And endogenous constraints related to the configuration of preferences maps (Leontief, Cobb-Douglas among other models), additional income effects (saving and unsaving effects), divisible nature of goods, risk aversion or nonutility-based optimization models (Ng 1972; Garrat 1997; Chambers et al. 2010; Haagsma 2012), even non-individual decisions (collective strategies, altruism, solidarity), indivisibility level between buyer and seller roles and speculative behaviours (Cortina 2011; Franco 2011).

There is a latent condition of Giffen inferiority in all goods, including normal goods. In other words, Giffen behaviour can also obtain in case of a normal good (Haagsma 2012; Minagawa 2012). Thus, an increase in the price of a good may reduce its demand only if the unsaving effect is less than the substitution effect (and the income effect). While a decrease in price will increase demand only if the saving effect is less than the substitution effect. Arguably, the analysis of downward sloping demand is a pre-scientific decision, a methodological bias and a decision of economic policy (a normative concept studied traditionally from the positive economy), according to the Haagsma's (2012), Havranek et al. (2012) and Attanasio et al. (2012) explanations too. 
The analysis of these effects helps us to understand the basics of Giffen demand, and serves to determine the impact that some policy measures can have on demand for a good or factor (labour). For example, backward sloping individual labour supply curve for high wages (e.g. Farzin 2009; Mochón 2010; Haagsma 2012).

\subsection{Consumer equilibrium}

Downward or Marshallian demand is often explained from the law of equality of weighted marginal utilities. However, the neoclassical explanation requires imposing a non-explicited additional constraint or correction factor which is usually ignored. This constraint establishes, according to the neoclassical theory, for all goods an unitary adjustment factor which the consumer makes to return to equilibrium in response to a change in the price of a particular good. This constraint is an oversimplification, since it excludes the Giffen goods. The formal expression Eq. (4) shows the extended law of equality of weighted marginal utilities:

$$
\boldsymbol{\beta}_{\boldsymbol{A}}^{*}\left(M U_{A} / P_{A}\right)=\boldsymbol{\beta}_{B}^{*}\left(M U_{B} / P_{B}\right),
$$

where $\beta$ is the correction factor for each good, $A$ and $B . M U$ denotes the marginal utility and $P$ the price of each good. When $\boldsymbol{\beta}_{A}$ and $\boldsymbol{\beta}_{B}$ are unitary we obtain the classical law of equality of weighted marginal utilities.

For a Giffen good, if its price decreases, then its demand also, thus its marginal utility increases as does its weighted marginal utility. To restore the equality in Eq. (4) then its correction factor has to be a fraction of its weighted marginal utility.

In sum, declines in the price of a Giffen good imply lower values (less than unity) of its corresponding correction factor. Rises in its price will lead to greater effort (correction factor greater than unity) on the part of the consumer to adjust the process of utility maximization. Moreover, Haagsma (2012) exposes that Marshall was redundant when justified the Law of Demand (downward slope) under the principle of diminishing marginal utility, because it supposes that all goods are normal.

\section{Giffen evidence in Spanish agrifood products?}

\subsection{A numerical example}

Giffen behaviour is probably more frequent than commonly thought. According to Jensen and Miller (2008), the subsistence goods "and the populations that exhibit Giffen behaviour, meet some basic but common conditions that suggest this behaviour may be widespread in the developing world. Thus, the absence of previously documented cases most likely results from inadequate data or empirical strategies rather than from their non-existence". However, the aggregate measure hides it (Haagsma 2012).

Table 5 shows a simple numerical example with hypothetical market scenarios. Prices decreases in A and B scenarios, where the Marshallian behaviour respond to increasing demanded quantity and the Giffen one decreasing it. In $C$ and $D$ scenarios the prices increases. The total population in our example is 100 . 
In scenario A the prices decreases from 10 to $8 \mathrm{~m}$.u. and the market demand increases from 260 to 340 units. Although there is some people with Giffen behaviour $\left(\mathrm{N}_{\mathrm{G}}=40\right)$, the market demand shows downward slope. Why? The reason is the Marshallian subdemand, it is more elastic than the Giffen demand.

In other situations, Giffen behaviour is hidden when only the total or aggregate demand is measured. However, if we subdivide the population between Marshallian and Giffen demand $\left(\mathrm{N}_{\mathrm{M}}\right.$ and $\left.\mathrm{N}_{\mathrm{G}}\right)$, linked high and low income levels $\left(\mathrm{Y}_{\mathrm{M}}\right.$ and $\left.\mathrm{Y}_{\mathrm{G}}\right)$, we can see that in scenario $\mathrm{B}$ the Giffen behaviour is observed at the aggregate level only if the price-elasticity of subdemand with low incomes $(E=3,33)$ is higher than the elasticity with higher incomes $(E=2,50)$, although the majority of the population shows a Marshallian behaviour $\left(\mathrm{N}_{\mathrm{M}}=60\right)$.

In other scenarios ( $C$ and $D)$ where income distribution is more unequal, but Giffen behaviour is a majority, this is not observable in aggregate demand (scenario $\mathrm{C}$ ), the reason is the Marshallian subdemand, it is more elastic than the Giffen subdemand (which is common in the agrifood sector) or even the opposite (scenario D). Thus, an unequal income distribution can show a downward demand function when the main behaviour is Giffen (upward). These observations imply different food policy according to income levels. Similar policy recommendations are also suggested, more cautiously, by Jensen and Miller (2008).

Table 5. The phenomenon of concealed Giffen Demand

\begin{tabular}{|c|c|c|c|c|c|}
\hline \multirow{2}{*}{$\begin{array}{l}\text { Hypothetical } \\
\text { Scenarios }\end{array}$} & \multirow[t]{2}{*}{ Prices (m.u.) } & \multicolumn{3}{|c|}{ Demanded individual quantities (units) } & \multirow{2}{*}{$\begin{array}{c}\text { Aggregate } \\
\text { Demand }\end{array}$} \\
\hline & & $\mathrm{Q}_{\mathrm{M}}$ & $\mathrm{Q}_{\mathrm{G}}$ & $\mathrm{Q}_{\text {market }}$ & \\
\hline \multirow{3}{*}{$\begin{array}{c}\mathrm{A} \\
\mathrm{N}_{\mathrm{M}}=60 \\
\mathrm{~N}_{\mathrm{G}}=40\end{array}$} & Initial point: $\mathrm{P}_{0}=10$ & 3 & 2 & 260 & \multirow{3}{*}{$\begin{array}{c}\text { Marshallian } \\
(\downarrow P \text { and } \uparrow Q)\end{array}$} \\
\hline & Final point: $P_{1}=8$ & 5 & 1 & 340 & \\
\hline & $\mid$ Elasticity $\mid$ & 3,33 & 2,50 & 1,54 & \\
\hline \multirow{3}{*}{$\begin{array}{c}\mathrm{B} \\
\mathrm{N}_{\mathrm{M}}=60 \\
\mathrm{~N}_{\mathrm{G}}=40\end{array}$} & Initial point: $\mathrm{P}_{0}=10$ & 2 & 3 & 240 & \multirow{3}{*}{$\begin{array}{c}\text { Giffen } \\
(\downarrow \mathrm{P} \text { and } \downarrow \mathrm{Q})\end{array}$} \\
\hline & Final point: $P_{1}=8$ & 3 & 1 & 220 & \\
\hline & $\mid$ Elasticity $\mid$ & 2,50 & 3,33 & 0,42 & \\
\hline \multirow{3}{*}{$\begin{array}{c}\mathrm{C} \\
\mathrm{N}_{\mathrm{M}}=20 \\
\mathrm{~N}_{\mathrm{G}}=80\end{array}$} & Initial point: $\mathrm{P}_{0}=8$ & 10 & 2 & 360 & \multirow{3}{*}{$\begin{array}{l}\text { Marshallian } \\
(\uparrow \mathrm{P} \text { and } \downarrow \mathrm{Q})\end{array}$} \\
\hline & Final point: $P_{1}=10$ & 4 & 3 & 320 & \\
\hline & $\mid$ Elasticity $\mid$ & 2,40 & 2,00 & 0,44 & \\
\hline \multirow{3}{*}{$\begin{array}{c}\mathrm{D} \\
\mathrm{N}_{\mathrm{M}}=10 \\
\mathrm{~N}_{\mathrm{G}}=90\end{array}$} & Initial point: $\mathrm{P}_{0}=8$ & 100 & 4 & 1.360 & \multirow{3}{*}{$\begin{array}{l}\text { Marshallian } \\
(\uparrow \mathrm{P} \text { and } \downarrow \mathrm{Q}\end{array}$} \\
\hline & Final point: $P_{1}=10$ & 70 & 6 & 1.240 & \\
\hline & $\mid$ Elasticity $\mid$ & 1,20 & 2,00 & 0,35 & \\
\hline
\end{tabular}

Elasticity $=|-(\Delta \mathrm{Q} / \mathrm{Q}) /(\Delta \mathrm{P} / \mathrm{P})|$. And aggregate demand is $\mathrm{Q}_{\text {market }}=\mathrm{N}_{\mathrm{M}} \mathrm{Q}_{\mathrm{M}}+\mathrm{N}_{\mathrm{G}} \mathrm{Q}_{\mathrm{G}}$

$\mathrm{N}_{\mathrm{M}}$ and $\mathrm{N}_{\mathrm{G}}$ are the number of population with downward and upward demand, respectively.

$\mathrm{Q}_{\mathrm{M}}$ and $\mathrm{Q}_{\mathrm{G}}$ are the demanded individual quantities by Marshallian and Giffen population, respectively.

Jensen and Miller (2008) suggest that it is possible to find more Giffen evidence in areas and countries with very impoverished populations. From Table 4 and the theoretical literature (Heijman, Von Mouche 2012) Giffen evidence can also be found in societies with great social differences, but not severe conditions of poverty according to Haagsma (2012). Likely there is Giffen evidence even in contexts where there is not extreme poverty or low incomes, but there are objective or perceived conditions of loss of social welfare, linked to low substitution levels between products in the short term. Some examples of products and services have become 
indispensable for people in developed countries are the following: mobile telephony, Internet access, car transportation, traditional fossil fuel, household appliances and leisure activities. If the price rise in any of these daily consumption products then could mean a Giffen change in consumption patterns, leading to a higher final consumption of new "necessary" goods to maintain the threshold level of acquired welfare.

\subsection{Spanish fruits and vegetables $2006-2010$}

According to the Spanish Institute of Statistic (INE 2010) the average net annual income per household is 26 thousand $€$ in 2007, 6\% more than in 2006. In 2008, households spent on average 32 thousand $€$ to consumer spending, which represents an annual rate of $-4.1 \%$ (eliminating the inflation effect). Among the groups most weight in the total expenditure, include increasing total spending on housing (6.2\%) and food and non-alcoholic beverages (2.3\%), while decreases in transportation and hotels, cafes and restaurants.

The average annual rate of change of prices of consumer goods and services during 2009 stood at $-0.3 \%$. The annual rate is $-1.1 \%$ on food. In 2009 , social spending on pensions (21\% GDP) increased, but still 5.2 percentage points below the EU-27 average. The annual growth rate of Gross Domestic Product is $-3.6 \%$. Employed people fell by $6.8 \%$ over 2008 . In 2009 it produced the second year of rising unemployment. Unemployed people increased by $60 \%$ over the previous year and over 4 million people.

In this section the Giffen-demand evidence is analyzed from official weekly data on Spanish agrifood (fresh fruits and vegetables) products prices in destination by Spanish Ministry of Environment, Rural and Marine Affairs (MARM 2011) and data on annual per capita consumption of fruits and vegetables by Spanish Federation of Associations of Producers and Exporters of Fruits, Vegetables, Flowers and Live Plants (FEPEX 2011) in Spain from 2006-2010. According to the last two paragraphs, it is assumed ceteris paribus condition in this period (no other variable significantly influences demand, but price changes). MARM price data are calculated by weighting national average prices in origin, wholesale and destination markets. Weekly prices in destination were obtained as the weighted average (Eq. (5)):

$$
P=\sum X_{i} Q_{i} / \Sigma Q_{i}
$$

where $X_{i}$ is the representative price of product $X$ in city $i$ and $Q_{i}$ is the weight of product $X$ in city $i$. Price in destination can be calculated by adding up the gross margin of each link of the commercial distribution chain. Destination prices are taken weekly from the best-selling varieties. This information is collected in local markets, traditional shops, supermarkets, hypermarkets and discount stores in province capital cities.

Table 6 shows from 2006 to 2010 the evolution of the average annual price and per capita consumption of various fruits and vegetables, common in the Spanish household's shopping basket. There is some Giffen evidence in onions, green beans, lettuce, lemon and apple, particularly in years when the crisis emerges. Why in some years the slope of the demand is increasing and other decreasing? This is probably due to the readjustment of the budget among the goods of the consumer basket, according to the step maximization process by $\mathrm{Ng}$ (1972). Moreover, in those years the credit crunch reduced the family purchasing power. The lack of disaggregated data by income level not allows us a better contrast of this phenomenon. 
Table 6. Aggregate demand behaviour in Spanish vegetables and fresh fruits (2007-2010)

\begin{tabular}{|c|c|c|c|c|c|c|}
\hline Products & Year & $\begin{array}{c}\text { Average } \\
\text { consumption } \\
\text { per capita } \\
{[\mathrm{a}]}\end{array}$ & $\begin{array}{c}\text { Average price } \\
€ / \mathrm{kg} \\
{[\mathrm{b}]}\end{array}$ & $\begin{array}{l}\% \text { interannual } \\
\text { growth of } \\
\text { consumption } p c \\
{[c]}\end{array}$ & $\begin{array}{l}\text { \% interannual } \\
\text { growth } \\
\text { of price } \\
\text { [d] }\end{array}$ & $\begin{array}{l}\text { Price elasticity of } \\
\text { demand } \\
{[\mathrm{e}]=-[\mathrm{c}][\mathrm{b}] /[\mathrm{d}][\mathrm{a}]}\end{array}$ \\
\hline \multirow[t]{5}{*}{ POTATO } & 2006 & 23.22 & 0.75 & & & \\
\hline & 2007 & 23.90 & 0.83 & 2.93 & 11.06 & -0.01 \\
\hline & 2008 & 24.16 & 0.81 & 1.09 & -2.82 & 0.01 \\
\hline & 2009 & 23.65 & 0.77 & -2.11 & -4.24 & -0.02 \\
\hline & 2010 & 23.35 & 0.81 & -1.27 & 5.16 & 0.01 \\
\hline \multirow[t]{5}{*}{ ONIONS } & 2006 & 7.00 & 0.92 & & & \\
\hline & 2007 & 7.17 & 1.18 & 2.43 & 28.04 & -0.01 \\
\hline & 2008 & 7.09 & 1.13 & -1.12 & -4.41 & -0.04 \\
\hline & 2009 & 7.42 & 1.08 & 4.65 & -4.49 & 0.15 \\
\hline & 2010 & 7.47 & 1.14 & 0.67 & 5.87 & -0.02 \\
\hline \multirow{5}{*}{$\begin{array}{l}\text { GREEN } \\
\text { BEAN }\end{array}$} & 2006 & 7.00 & 3.67 & & & \\
\hline & 2007 & 7.17 & 3.78 & 2.43 & 2.90 & -0.44 \\
\hline & 2008 & 7.09 & 3.76 & -1.12 & -0.56 & -1.06 \\
\hline & 2009 & 7.42 & 3.63 & 4.65 & -3.48 & 0.65 \\
\hline & 2010 & 7.47 & 3.49 & 0.67 & -3.76 & 0.08 \\
\hline \multirow[t]{5}{*}{ LETTUCE } & 2006 & 5.52 & 0.87 & & & \\
\hline & 2007 & 5.27 & 0.90 & -4.53 & 3.32 & 0.23 \\
\hline & 2008 & 5.05 & 0.89 & -4.17 & -0.30 & -2.45 \\
\hline & 2009 & 4.91 & 0.87 & -2.77 & -2.72 & -0.18 \\
\hline & 2010 & 4.84 & 0.92 & -1.43 & 6.06 & 0.04 \\
\hline \multirow[t]{5}{*}{ BANANA } & 2006 & 8.99 & 1.840 & & & \\
\hline & 2007 & 9.94 & 1.765 & 10.57 & -4.11 & 0.46 \\
\hline & 2008 & 10.11 & 1.879 & 1.71 & 6.50 & -0.05 \\
\hline & 2009 & 9.46 & 1.894 & -6.43 & 0.78 & 1.65 \\
\hline & 2010 & 11.22 & 1.704 & 18.60 & -10.05 & 0.28 \\
\hline \multirow[t]{5}{*}{ LEMON } & 2006 & 1.92 & 1.35 & & & \\
\hline & 2007 & 1.95 & 1.39 & 1.56 & 2.73 & -0.41 \\
\hline & 2008 & 1.99 & 1.94 & 2.05 & 40.14 & -0.05 \\
\hline & 2009 & 2.11 & 1.51 & 6.03 & -22.40 & 0.19 \\
\hline & 2010 & 2.16 & 1.71 & 2.37 & 13.35 & -0.14 \\
\hline \multirow[t]{5}{*}{ APPLE } & 2006 & 11.27 & 1.57 & & & \\
\hline & 2007 & 11.50 & 1.72 & 2.04 & 9.33 & -0.03 \\
\hline & 2008 & 11.73 & 1.78 & 2.00 & 3.70 & -0.08 \\
\hline & 2009 & 11.40 & 1.66 & -2.81 & -6.71 & -0.06 \\
\hline & 2010 & 12.13 & 1.58 & 6.40 & -4.86 & 0.17 \\
\hline
\end{tabular}

Note: in bold the Giffen evidence (ceteris paribus). The lettuce price is measured in $€ /$ unit.

Source: Author from MARM (2011) and FEPEX (2011). 
The banana is an example of concealed Giffen behaviour related to the problem of the aggregate measure. Thus, disaggregating the commercialized quantity to the Peninsula and the Canary Islands (Table 7), we can see that in 2008 prices have risen compared to 2007, and the demanded quantity in the Peninsula and the Canary Islands too. The following year, the demanded peninsular quantity declines, however, the insular quantity increases, although the average per capita demand down in 2009 as shown in Table 6.

Table 7. Evolution of prices and consumption of bananas in Spain (Peninsula and Canary Islands)

\begin{tabular}{ccccccc}
\hline Year & $\begin{array}{c}\text { Average } \\
\text { Price } \\
€ / \mathrm{kg}\end{array}$ & $\begin{array}{c}\text { \% interanual } \\
\text { Growth }\end{array}$ & $\begin{array}{c}\text { Peninsular } \\
\text { consumption } \\
\text { (Ton.) }\end{array}$ & $\begin{array}{c}\text { \% interanual } \\
\text { growth }\end{array}$ & $\begin{array}{c}\text { Insular } \\
\text { consumption } \\
\text { (Ton.) }\end{array}$ & $\begin{array}{c}\text { \% interanual } \\
\text { growth }\end{array}$ \\
\hline 2005 & 1.889 & & 315.468 & & 29.455 & \\
\hline 2006 & 1.840 & -2.57 & 318.186 & 0.86 & 30.030 & 1.95 \\
\hline 2007 & 1.765 & -4.11 & 326.518 & 2.62 & 31.255 & 4.08 \\
\hline 2008 & 1.879 & $\mathbf{6 . 5 0}$ & 338.397 & $\mathbf{3 . 6 4}$ & 32.451 & $\mathbf{3 . 8 3}$ \\
\hline 2009 & 1.894 & $\mathbf{0 . 7 8}$ & 318.054 & -6.01 & 33.604 & $\mathbf{3 . 5 5}$ \\
\hline 2010 & 1.704 & -10.05 & 356.577 & 12.11 & 39.374 & 17.17 \\
\hline
\end{tabular}

Note: in bold the Giffen evidence (ceteris paribus).

Source: Author from MARM (2011) and ASPROCAN (2011).

Several linear econometric models have been estimated from available weekly prices and quantities of banana from 2005 to 2010 (Table 8). We have estimated one model for each year and another additional model for the whole period. The generic specification of each model (Eq. (6)) is the demand function (ceteris paribus):

$$
Q=a+b P,
$$

where $Q$ is the amount of banana $(\mathrm{kg})$ sold weekly. $P$ is the weekly average price of banana $(€ / \mathrm{kg})$. And $a$ is the constant and $b$ shows the slope of the function. According to the sign of $b$ and to its level of significance we can define if the demand is upward or downward sloping.

Table 8. OLS estimates of Spanish banana demand function from 2005 to 2010 in ceteris paribus conditions

\begin{tabular}{ccccc}
\hline Year & $\begin{array}{c}\text { Sign of } \\
\text { constant "a" }\end{array}$ & $\begin{array}{c}\text { Sign of } \\
\text { coefficient "b" }\end{array}$ & $\begin{array}{c}\mathrm{N} \\
\text { (weeks) }\end{array}$ & Slope of demand \\
\hline 2005 & - (n.s.) & $+\left(^{* *}\right)$ & 52 & Upward \\
\hline 2006 & - (n.s.) & $+\left(^{* *}\right)$ & 52 & Upward \\
\hline 2007 & $+\left(^{* * *}\right)$ & $-\left(^{* *}\right)$ & 52 & Downward \\
\hline 2008 & $+\left(^{* *}\right)$ & $-($ n.s. & 52 & Downward \\
\hline 2009 & $-($ n.s. & $+\left(^{* *}\right)$ & 53 & Upward \\
\hline 2010 & $+\left(^{* *}\right)$ & $-\left(^{*}\right)$ & 52 & Downward \\
\hline $2005-2010$ & $+\left(^{* *}\right)$ & $-\left(^{* *}\right)$ & 313 & Downward \\
\hline
\end{tabular}

Note: Weekly data from MARM (2011) and ASPROCAN (2011). Software: Limdep v. 8.0.

Levels of significance: $\mathrm{p}<0.01^{\star * *}<0.05^{\star *}<0.10^{\star}$ 
Table 8 summarizes the OLS estimates of the demand function of Spanish banana (2005-2010) from the weekly data of average price by MARM (2011) and commercialized production in Spanish Peninsula by The Canary Islands' Association of Banana Producers (ASPROCAN 2011). The period 2005-2010 shows a downward sloping demand, however, many years have shown upward sloping demand. A detailed descriptive study, week by week, reveals that more than half weeks each year Giffen behaviour has been observed. These results confirm the analysis of the theoretical literature (Heijman, Von Mouche 2012) and also show other example of concealed Giffen demand because of the aggregation effect explained numerically in Table 5. Nevertheless more researches and disaggregated data are necessary to contrast empirically this result.

The Giffen phenomenon is recognised at the individual level; however, empirical evidence at the aggregate (market) level is not large. Earlier attempts to demonstrate its existence have been discredited because the data were not correctly interpreted or analysed. However some evidence have been reported (Battalio et al. 1991; McKenzie 2002; Jensen, Miller 2008).

\section{Policy recommendations}

There are several policy recommendations related to the theoretical and empirical results of this study. The next policy recommendations are framed, in a general way, in the next scheme (Fig. 4).

\begin{tabular}{|c|c|}
\hline Critical theoretical analysis & Critical empirical analysis \\
$\downarrow$ & $\downarrow$ \\
\hline Giffen phenomenon & Neoliberal globalization of poverty \\
$\downarrow$ & $\downarrow$ \\
\hline Discovery of ignored effects & Alternative economic proposal \\
$\downarrow$ & $\downarrow$ \\
\hline \multicolumn{2}{|c|}{ Economy based on Human Rights and environmental sustainability } \\
\hline \multicolumn{2}{|c|}{ THE NEW POLITICAL ECONOMY } \\
\hline
\end{tabular}

Fig. 4. General scheme for the future development of policy recommendations

At the theoretical level, we can emphasize economic policies about degrowth and employment according to the economic cycle. Particularly, both expansive and depressive phases derive various employment policies according to the relative elasticity of the curves. Thus, in economic expansion period, it can stimulate job creation in sectors where demand is usually more rigid (agricultural commodities) and siphoning off labour from the luxury goods sector (demand more sensitive than supply). Besides it contributes to adoption of degrowth economic models, guarantors of food sovereignty and security. But when the economy is in recession period, it should stimulate job creation in both primary goods and luxury sectors, 
in order to transfer the extra income from the luxury sector to the primary goods sector to curb the fall in demand for subsistence. Although, it seems as if the depressive phase would be suggesting stimulation of speculative behaviour in luxury markets. In reality it seeks to promote the upwelling of savings to support the subsistence level of demand and avoid the exclusion of consumers with low purchasing power.

Speculative practices are inherent in the markets with Giffen demand. Negative effects of speculation are more severe and frequent in crisis period. They may originate in any of the scenarios described in Tables 4 . In these cases a way of slowing down or reversing the impact is through active employment policies, controlling the supply or demand reduction by keeping close to the limit at which prices rise, but without going over, while the flow of savings is redirected towards the financing of primary food consumption. Speculation is more difficult to control in basic food markets because demand is more rigid than supply, unless demand contracts due to the expulsion of consumers with low purchasing power.

Some policy recommendations from the empirical analysis are the next. The Giffen analysis suggests the classification of demand according to income levels and consumer behaviour with respect to price changes. It also indicates a better design of specific agrifood policies for each type/segment of sub-demand. Redistributive measures become essential in these Giffen scenarios. Nutrition programmes suggested by Jensen and Miller (2008) point out in this direction. A direct consequence of this approach is the development of three complementary policies:

- Social policy based on the development of "basic income" models. Regarding economic policy on the citizen right to "basic income", we can highlight the main objective of this redistributive proposal, that is, the eradication of poverty (Iglesias 2008). This economic measure would avoid the worst consequences of Giffen behaviour;

- Fiscal policy based on the design of corrective mechanisms of speculation in food prices. From the adoption of a more progressive fiscal system at the national and supranational levels to the design of new eco-taxes and Tobin tax. It would helps to reduce the negative effects of speculation process in agrifood markets and the impoverishment of people most vulnerable;

- Financial policy based on direct control of speculation and its impact on the food market (e.g. Navarro, Torres 2012). This economic policy is closely related to the previous. The main topics are two: international financial regulation and abolition of tax havens.

Another set of economic policies are programs to promote agribusiness cooperatives to minimize the negative impact of multinational firms, as some reports suggest too (Uclés, Cabrera 2009), especially in the current context of globalization.

\section{Conclusions}

The main conclusions are twofold, at the theoretical and empirical levels. For one thing, theoretical remarks associated with (exogenous and endogenous) additional constraints, besides the individual budget constraint, to explain the aggregated demand behaviour. Particularly, the ethical interpretation of these "restrictions", they are not really restrictions, but 
better approximations to economic reality about human nature and consumer behaviour. Moreover, the "Giffen behaviour" is a major criticism of the main neoclassical laws (upward supply, downward demand and "natural" equilibrium between supply and demand without public sector intervention). Even the dominant paradigm hides the choice paradox under the misunderstood Giffen paradox.

For another thing, empirical results about the consumption pattern of horticultural products in Spain during the crisis period show (with the above caveats and assumptions) that there is no an unequivocal demand behaviour, alternating Marshallian and Giffen attitudes. Particularly, it is observed upward demand slightly in bananas, potatoes and onions, and stronger in green bean, lettuce, lemon and apple. Besides, there is some evidence of concealed Giffen demand in the consumption of banana between 2008 and 2009.

There is a need for new theoretical and empirical studies that examine in greater depth each contribution of this paper. Of particular interest, following the thread of the Giffen demand theory, is the effort to develop an analytical framework that is an alternative to the neoclassical paradigm, reintroducing the ethical dimension of the economics (political economy), investigating what place is occupied in the new scheme by economic proposals as the Tobin tax, theories of negative growth or de-growth, models of basic income, micro-credits, fair trade, ecological economics, sustainable economy, gender socioeconomics, etc. All of them related to the fight against poverty (traditional factor of generation of Giffen behaviour).

The main limitations of this research are related to the lack of disaggregated data by income levels and the ceteris paribus condition. Thus MARM (2011) adds in its methodological note: Price information (in origin, wholesale and destination) collects data produced by each of the sources with their own specifications and, therefore, are not homogeneous magnitudes when making comparisons, though, of course, are of useful to evaluate trends within each channel and the entire business chain. Moreover, the final formation of prices is influenced by the following factors: the variety of tastes and preferences of consumers, and their highest demands in terms of traceability, quality and environmental compatibility of products purchased.

From the last paragraph we can draw several future research lines (framed in Fig. 4). It is considered of especial interest to obtain primary information by means of consumer questionnaires in order to avoid the effect of data aggregation. Another lines would deal with a deeper analysis of Giffen behaviour for alternative economic proposals and other nonutility-based approaches (e.g. Ng 1972; Garrat 1997), and with the relationships between Giffen phenomenon and poverty according to the AROPE (At Risk Of Poverty and/or Exclusion) European indicator.

\section{Acknowledgements}

The author is grateful to Jesús Barreiro-Hurlé and Jorge García-Arias for their valuable comments on earlier drafts of this article, as well as to the reviewers. 


\section{References}

ASPROCAN 2011. Production of Canarian bananas commercialized (2005-2010) [online], [cited 19 October 2011]. The Canary Islands' Association of Banana Producers [Asociación de Organizaciones de Productores de Plátanos de Canarias]. Available from Internet: http://www.platanodecanarias. net/app/webroot/en/cifras.php

Attanasio, O. P.; Bottazzi, R.; Lowd, H. W.; Nesheima, L.; Wakefield, M. 2012. Modelling the demand for housing over the life cycle, Review of Economic Dynamics 15(2): 1-18. http://dx.doi.org/10.1016/j.red.2011.09.001

Battalio, R.; Kagel, J.; Kogut, C. 1991. Experimental confirmation of the existence of a Giffen good, American Economic Review 81: 961-978.

Blanco, J. M. 2008. Economía. Teoría y práctica. $5^{\text {th }}$ ed. McGraw-Hill. 451 p.

Chambers, C. P.; Echenique, F.; Shmaya, E. 2010. On behavioral complementarity and its implications, Journal of Economic Theory 145: 2332-2355. http://dx.doi.org/10.1016/j.jet.2010.08.004

Cortina, A. 2011. Neuroética y neuropolítica. Sugerencias para la educación moral. Tecnos. 262 p.

Dwyer, G.; Lindsay, C. 1984. Robert Giffen and the Irish potato, American Economic Review 74: 188-192.

Farzin, Y. H. 2009.The effect of non-pecuniary motivations on labor supply, The Quarterly Review of Economics and Finance 49: 1236-1259. http://dx.doi.org/10.1016/j.qref.2009.09.001

FEPEX 2011. Sector data. Spanish Federation of Associations of Producers and Exporters of Fruits, Vegetables, Flowers and Live Plants [Federación Española de Asociaciones de Productores y Exportadores de Frutas, Hortalizas, Flores y Plantas Vivas] [online], [cited 18 October 2011]. Available from Internet: http://www.fepex.es/publico_en/presentacion/QueEsFepex.aspx

Fernández-Huerga, E. 2008. The economic behavior of human beings: the institutional/Post-Keynesian model, Journal Economic Issues 42(3): 709-726.

Franco, J. A. 2011. Analysis of Giffen behaviour in agrifood markets: Working Paper, Unpublished manuscript, University of Extremadura. $140 \mathrm{p}$.

Garratt, R. 1997. Indivisibilities, inferior goods and Giffen goods, Canadian Journal of Economics 30(1): 246-251. http://dx.doi.org/10.2307/136370

Georgescu-Roegen, N. 1954. Choice, expectations and measurability, Quarterly Journal of Economics 48(4): 503-534. http://dx.doi.org/10.2307/1881875

Haagsma, R. 2012. Notes on some theories of Giffen behaviour, in W. Heijman, P. Von Mouche (Eds.). New insights into the theory of Giffen goods. Springer, 5-19.

Havranek, T.; Irsova, Z.; Janda, K. 2012. Demand for gasoline is more price-inelastic than commonly thought, Energy Economics 34: 201-207. http://dx.doi.org/10.1016/j.eneco.2011.09.003

Heijman, W.; Von Mouche, P. (Eds.). 2012. New insights into the theory of Giffen goods. Springer. 171 p. http://dx.doi.org/10.1007/978-3-642-21777-7

Huck, S.; Rasul, I. 2011. Matched fundraising: evidence from a natural field experiment, Journal of Public Economics 95: 351-362. http://dx.doi.org/10.1016/j.jpubeco.2010.10.005

Iglesias, J. 2008. Basic income for equal citizens, in International Congress on Basic Income for Equal Citizens [online], [cited 09 May 2012], 24-26 October 2008, Berlin. Available from Internet: http:// www.rentabasica.net/RBdelosiguales_EN.pdf

INE 2010. España en cifras 2010. INE [Spanish Institute of Statistic] [online], [cited 16 January 2012]. Available from Internet: www.ine.es

Jensen, R.; Miller, N. 2008. Giffen behavior and subsistence consumption, American Economic Review 98(4): 1553-1577. http://dx.doi.org/10.1257/aer.98.4.1553 
Kamphorst, J. J. A.; Swank, O. H. 2013. When Galatea cares about her reputation: how having faith in your workers reduces their motivation to shine, European Economic Review 60: 91-104. http://dx.doi.org/10.1016/j.euroecorev.2013.02.004

Luptacik, M. 2010. Mathematical optimization and economic análisis. Springer. 307 p. http://dx.doi.org/10.1007/978-0-387-89552-9

MARM 2011. Origin-Destination food price monitoring centre [online], [cited 17 October 2011]. Spanish Ministry of Environment, Rural and Marine Affairs [Ministerio de Medio Ambiente y Medio Rural y Marino]. Available from Internet: http://www.magrama.gob.es/es/estadistica/temas/estadisticas-agrarias/economia/observatorio-precios-alimentacion/

Marshall, A. 1890. Principles of economics. MacMillan and Co. 754 p.

McKenzie, D. 2002. Are tortillas a Giffen good in Mexico?, Economic Bulletin 15: 1-7.

Medina, J. M.; Cascante, K. 2011. Especulación financiera y crisis alimentaria [online], [cited 02 May 2012]. Campaign “The right to food. Urgent.”, Prosalus, Ongawa, Cáritas Española, Ayuda en Acción. Available from Internet: http://www.derechoalimentacion.org

Minagawa, J. 2012. On Giffen-like goods, Economics Letters 115: 282-285. http://dx.doi.org/10.1016/j.econlet.2011.12.039

Minten, B.; Murshid, K. A. S.; Reardon, T. 2013. Food quality changes and implications: evidence from the rice value chain of Bangladesh, World Development 42: 100-113. http://dx.doi.org/10.1016/j.worlddev.2012.06.015

Mochón, F. 2010. Principios de Economía. $4^{\text {th }}$ ed. McGraw-Hill. 409 p.

Navarro, V.; Torres, J. 2012. Los amos del mundo. Las armas del terrorismo financiero. Espasa. 214 p.

Ng, Y. K. 1972. Step-optimization, secondary constraints and Giffen goods, Canadian Journal of Economics 5(4): 553-560. http://dx.doi.org/10.2307/134019

Silberberg, E.; Walker, D. 1984. A modern analysis of Giffen paradox, International Economic Review 25: 684-694. http://dx.doi.org/10.2307/2526227

Stigler, G. 1947. Notes on the history of the Giffen paradox, Journal of Political Economy 55: 152-156. http://dx.doi.org/10.1086/256487

Torres, J. M.; Córdoba, J. L. 1992. Principios y objetivos del marketing. Deusto. 188 p.

Uclés, D.; Cabrera, A. 2009. El nuevo sistema agroalimentario. Retos para el cooperativismo agrario andaluz. Cajamar Foundation. 130 p.

Xingang, Z.; Pingkuo, L. 2013. Substitution among energy sources: an empirical analysis on biomass energy for fossil fuel of China, Renewable and Sustainable Energy Reviews 18: 194-202. http://dx.doi.org/10.1016/j.rser.2012.10.028

J. Agustín FRANCO. He is Dr and Associate Professor at the Economics Department in Faculty of Law in Cáceres. He was an Assistant Professor of Statistics at the University of Zaragoza from 2006 to 2009. He defended his Doctoral Thesis on Agrarian Economy at the University of Córdoba in March 2009. He is author of several papers in the field of natural resources conservation and agrarian sustainability. His research interests include applied economics from a critical approach, environmental economics and gender studies. 